УДК 378.048 .02

\title{
ПРОГРАМА НАВЧАЛЬНОЇ ДИСЦИПЛІНИ “АНГЛІЙСЬКА МОВА ПРОФЕСІЙНОГО СПРЯМУВАННЯ”
}

Тітова В. М., Котиш Н. А., Бобер Н. М., Мачуський В. В.

boss.intensive@gmail.com; laviya@i.ua; natashabober@gmail.com; ghostdfs@gmail.com

Навчально-науковий інститут "Юридичний інститут ДВНЗ

"Київський національний економічний університет імені Вадима Гетьмана"

Дата надходження 07.02.2018. Рекомендовано до друку 30.04.2018.

У публікації представлено проект програми навчальної дисципліни “Англійська мова професійного спрямування” (ESP, вхідний рівень володіння англійською мовою В1) для студентів першого (бакалаврського) рівня, які навчаються за спеціальністю 081 Правознавство. Сформульовано мету й завдання навчальної дисципліни. Конкретизовано змістове наповнення їі чотирьох модулів. Зазначено технології формування професійно орієнтованої іншомовної комунікативної компетентності майбутнього правознавця та форми індивідуальної роботи студента.

Ключові слова: іноземна мова, майбутні правознавці, професійно орієнтована іншомовна комунікативна компетентність.

Титова В. М., Котыш Н. А., Бобер Н. Н., Мачуский В. В. Учебно-научный институт “Юридический институт Государственного высшего учебного заведения “Киевский национальный экономический университет имени Вадима Гетьмана"

Программа учебной дисциплины “Английский язык для профессиональных целей”

В публикации представлена программа учебной дисциплины “Английский язык для профессиональных целей” (ESP, входной уровень владения английским языком В1) для студентов первого (бакалаврского) уровня, которые обучаются на специальности 081 Правоведение. Сформулированы цель и задания учебной дисциплины. Конкретизировано содержательное наполнение её четырех модулей. Обозначены технологии формирования профессионально ориентированной иноязычной коммуникативной компетентности будущего юриста и формы индивидуальной работы студента.

Ключевые слова: иностранный язык, будущие юристы, профессионально ориентированная иноязычная коммуникативная компетентность

Titova V., Kotysh N., Bober N., Machuskyi V. Academic and Research Institute "Law Institute of State Higher Educational Institution "Kyiv National Economic University named after Vadym Hetman" Syllabus of the course "English for Specific Purposes"

The publication presents the project of the syllabus of the course "English for Specific Purposes" for students of the first (bachelor) level majoring in 081 Law (entry level of the English language knowledge B1). The aim and tasks of the course are stated. The context of its four modules is defined concretely. Some technologies of forming professionally oriented foreign language communicative competence of the prospective lawyer and forms of students' self-study work are identified.

Keywords: foreign language, prospective legal professionals, professionally oriented foreign language communicative competence.

Створення єдиного загальноєвропейського простору зумовило значні зміни в різних сферах суспільного життя, зокрема й у сфері вищої освіти, та висунуло низку сучасних вимог щодо особистості майбутнього фахівця. Сьогодні суспільство очікує на фахівця інноваційного типу з високим рівнем сформованості професійної компетентності, який буде здатний гідно співпрацювати $з$ представниками інших культур.

Перед сучасною системою вищої освіти постає складне завдання - підготувати фахівця, здатного як вирішувати питання, пов'язані безпосередньо з його професійною діяльністю, так й у разі потреби працювати в міжнародному контексті, мати позитивне ставлення до несхожості й інших культур, вміти коректно користуватися набутими лінгвосоціокультурними знаннями для досягнення своїх цілей в іншомовному спілкуванні. 
Потреба у володінні іноземною мовою професійного спрямування як засобом міжкультурного спілкування стає значущою в становленні особистості майбутнього фахівця.

Навчання іноземної мови професійного спрямування, передусім, передбачає формування у студентів здатності користуватись іноземною мовою в конкретних професійних, ділових, наукових сферах і ситуаціях спілкування із урахуванням особливостей професійного мислення. Спілкування іноземною мовою професійного спрямування допомагає особистості розвиватись, підвищувати свій загальний, інтелектуальний і фаховий рівні.

Навчальна програма “Англійська мова професійного спрямування” (АМПС) розроблена для студентів Навчально-наукового інституту "Юридичний інститут ДВНЗ “Київський національний економічний університет імені Вадима Гетьмана", які навчаються за освітньопрофесійною програмою підготовки бакалавра за спеціальністю "Правознавство", напрям підготовки 081, галузь знань "Право" (08), кваліфікація “Бакалавр з права" з вхідним рівнем володіння англійською мовою (РВМ) В1. Навчальну програму складено згідно з вимогами кредитно-модульної системи організації навчання, рекомендаціями програми "English for Specific Purposes (ESP) National Curriculum for Universities" (Англійська мова професійного спрямування), Загальноєвропейських рекомендацій з мовної освіти, "Концепції державної мовної політики України", новітніх досліджень і рекомендацій щодо реалізації компетентнісного підходу в навчанні іноземних мов як засобу комунікації в діалозі культур тощо.

У навчальній програмі здійснено спробу визначити нормативні обсяги знань, які має здобути студент відповідно до вимог стандартів вищої освіти; алгоритм вивчення дидактичного матеріалу навчальної дисципліни; необхідне методичне забезпечення; методи й технології навчання студентів й очікувані результати навчання. Програма розрахована на досягнення PBM В2, який $є$ стандартом для ступеня бакалавра.

Предметом вивчення дисципліни (згідно з ОПП ГСВО МОНУ) є обсяг фахової лексики, мовних, мовленнєвих, функціональних і граматичних структур англійської мови, що уможливлює професійне усне й писемне спілкування, а також набуття необхідної професійної інформації 3 англомовних джерел.

Завдання навчальної дисципліни полягають у гармонійному формуванні у студентів майбутніх юристів - іншомовної комунікативної компетентності (ІКК) у:

- говорінні (професійно орієнтованому монологічному, діалогічному й полілогічному мовленні);

- читанні й аудіюванні (розуміння англомовних текстів різноманітного цільового призначення тощо);

- письмі (писати професійні тексти і документи, ділові й професійні листи, демонструючи міжкультурне розуміння й попередні знання в конкретному професійному контексті), а також ознайомленні студентів з базовими положеннями, які складають підгрунтя сучасної професійної юридичної комунікації в умовах глобального суспільства.

Міждисциплінарні зв'язки. Викладання навчальної дисципліни “Англійська мова професійного спрямування” корелює зі змістом фахових навчальних дисциплін, як-то: “Логіка" (юридична логіка), "Риторика”, “Юридичне документознавство”, "Культура професійного мовлення”, “Теорія держави і права”, “Господарське право”, “Кримінальне право”, “Цивільне право”, “Міжнародне право” тощо.

Практична мета навчальної дисципліни “Англійська мова професійного спрямування" полягає у формуванні у студентів професійно орієнтованої міжкультурної комунікативної компетентності (МКК), яка охоплює мовні, мовленнєві, лінгвосоціокультурну й навчальностратегічну компетентності для забезпечення ефективної міжкультурної комунікації в академічному й професійому середовищі.

Процес формування професійно орієнтованої МКК витлумачується як мовленнєва поведінка майбутнього фахівця, яка вимагає оволодіння ним мовними й мовленнєвими компетентностями 
в поєднанні з лінгвосоціокультурною й навчально-стратегічною компетентностями, необхідними для виконання навчальних і професійних завдань. Розвиток професійно орієнтованої МКК здійснюється з урахуванням здатності студентів учитись, їхніх предметних знань і попереднього досвіду в межах ситуативного контексту, пов'язаного з навчанням і спеціалізацією.

Іншомовні компетентності й відповідні їм результати навчання

Таблиия

\begin{tabular}{|c|c|}
\hline \multicolumn{2}{|c|}{ Компетентності } \\
\hline \multicolumn{2}{|r|}{ І. Мовні компетентності } \\
\hline $\begin{array}{l}\text { Лексична } \\
\text { компетентність } \\
\text { (ЛК) }\end{array}$ & $\begin{array}{l}\text { •коректно вживати лексичні одиниці активного мінімуму (компетентності } \\
\text { в говорінні й письмі) згідно із ситуаціями спілкування й цілями } \\
\text { комунікації } \\
\text { •розпізнавати й розуміти лексичні одиниці активного й пасивного } \\
\text { мінімумів при читанні й аудіюванні } \\
\text { •аналізувати англомовні джерела інформації для отримання даних, } \\
\text { необхідних для виконання професійних завдань і прийняття професійних } \\
\text { рішень } \\
\text { •користуватися різними видами словників (дво-, одномовними, } \\
\text { фразеологічними, тематичними, країнознавчими) }\end{array}$ \\
\hline $\begin{array}{l}\text { Граматична } \\
\text { компетентність } \\
\text { (ГК) }\end{array}$ & $\begin{array}{l}\text { - коректно вживати видо-часові форми й категорії стану дієслів; } \\
\text { основні категорії іменника, прикметника, прислівника; артиклів тощо } \\
\text { • використовувати модальні дієслова і розуміти відтінки їхніх } \\
\text { значень } \\
\text { • правильно й доречно використовувати граматичні структури в різних } \\
\text { мовленнєвих ситуаціях } \\
\text { • складати різні речення (розповідні, питальні, спонукальні) залежно } \\
\text { від мети спілкування й характеру мовленнєвого акту } \\
\text { • демонструвати знання синтаксичної організації англійської мови } \\
\text { в спілкуванні тощо }\end{array}$ \\
\hline $\begin{array}{l}\text { Фонетична } \\
\text { компетентність } \\
\text { (ФК) } \\
\end{array}$ & $\begin{array}{l}\text { - сприймати фонеми й відтворювати їх у певному контексті } \\
\text { • сприймати й відтворювати фонетичний склад як окремих лексичних } \\
\text { одиниць, так і цілого речення. }\end{array}$ \\
\hline $\begin{array}{l}\text { Компетентності } \\
\text { в техніці } \\
\text { письма (КТП) i } \\
\text { читання (КТЧ) }\end{array}$ & $\begin{array}{l}\text { • коректно графічно й орфографічно оформлювати писемне } \\
\text { висловлювання } \\
\text { • свідомо розпізнавати й озвучувати графічні одиниці } \\
\text { • читати тексти } 3 \text { дотриманням відповідної інтонації й швидкості } \\
\text { читання тощо }\end{array}$ \\
\hline \multicolumn{2}{|r|}{ ІІ. Мовленнсві компетентності } \\
\hline $\begin{array}{l}\text { Компетентність } \\
\text { в аудіюванні } \\
\text { (КА) }\end{array}$ & $\begin{array}{l}\text { • розуміти зміст й уміти відповісти на запитання про загальну } \\
\text { й специфічну інформацію щодо своєї спеціалізації } \\
\text { • розуміти автентичні аудіо- й відеоматеріали з незначною кількістю } \\
\text { незнайомої термінології } \\
\text { • розуміти основні ідеї й розпізнавати відповідну інформацію в ході } \\
\text { обговорень, дебатів, доповідей, бесід, тематично пов'язаних із навчанням } \\
\text { і спеціальністю } \\
\text { • розуміти обговорення проблем загальнонаукового й професійно } \\
\text { орієнтованого характеру, що має на меті досягнення порозуміння } \\
\text { • розуміти складні повідомлення й інструкції в академічному } \\
\text { й професійному середовищі }\end{array}$ \\
\hline
\end{tabular}


Продовження табл.

\begin{tabular}{|c|c|}
\hline & $\begin{array}{l}\text { - розуміти намір мовця й комунікативні наслідки його висловлювання } \\
\text { • визначати свою позицію і точку зору } \\
\text { • переказувати іноземною мовою зміст прослуханого професійно } \\
\text { орієнтованого чи соціально-політичного тексту, який грунтується } \\
\text { на вивченому лексико-граматичному матеріалі } \\
\text { - визначати позицію й точку зору мовця тощо }\end{array}$ \\
\hline $\begin{array}{l}\text { Компетентність } \\
\text { у говорінні } \\
(\text { КГ) }\end{array}$ & 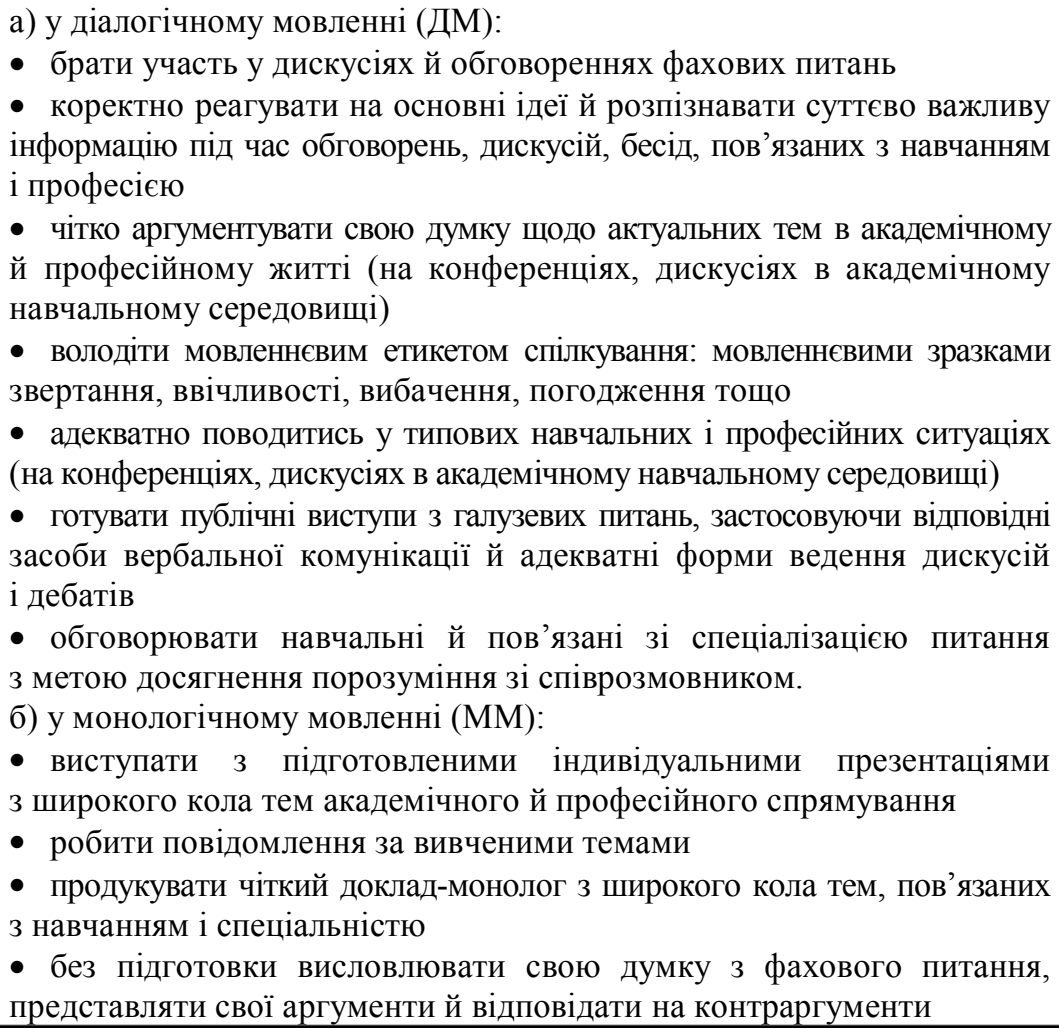 \\
\hline $\begin{array}{l}\text { Компетентність } \\
\text { у читанні (КЧ) }\end{array}$ & $\begin{array}{l}\text { • Ознайомлювальне читання: розуміти текст професійно спрямованої } \\
\text { тематики, ідентифікувати основну інформацію, виокремлювати певні } \\
\text { факти й аргументи } \\
\text { • Переглядове читання: визначати коло питань, які розглядаються } \\
\text { в тексті, та основні думки автора тексту } \\
\text { • Пошукове читання: знаходити певну інформацію в довідкових } \\
\text { джерелах; текстову, графічну, аудіо-/відео інформацію, вміщувану } \\
\text { в англомовних галузевих матеріалах (як у друкованому, так } \\
\text { і в електронному вигляді), користуючись відповідними пошуковими } \\
\text { методами і термінологією } \\
\text { • Вивчаюче читання: вільно, фонетично правильно читати } \\
\text { текст загальноюридичного, соціально-політичного, країнознавчого } \\
\text { й побутового характеру, укладений чи дібраний на основі вивченого } \\
\text { лексико-граматичного матеріалу } \\
\text { • критично оцінювати прочитані тексти зі сфери майбутнього фаху, } \\
\text { оцінювати точність викладу інформації та їі інтерпретацію }\end{array}$ \\
\hline
\end{tabular}


Продовження табл.

\begin{tabular}{|c|c|}
\hline $\begin{array}{l}\text { Компетентність } \\
\text { у письмі (КП) }\end{array}$ & $\begin{array}{l}\text { • письмово викласти зміст прочитаного / прослуханого тексту, } \\
\text { укладеного / дібраного на основі вивченого лексико-граматичного } \\
\text { матеріалу } \\
\text { • } \quad \text { занотувати прослуховуване } \\
\text { • писати план і тези виступу } \\
\text { • писати CV / резюме, протокол тощо з високим ступенем граматичної } \\
\text { коректності } \\
\text { • писати твір / есе в межах вивченої тематики } \\
\text { • готувати ділову й професійну документацію / кореспонденцію тощо }\end{array}$ \\
\hline
\end{tabular}

Основні вимоги до мовних компетентностей

Лексична компетентність (ЛК). Добирання лексичного мінімуму зумовлено академічними й професійними сферами й мовленнєвими ситуаціями, в яких вони вживаються. Опанування студентами іншомовної лексичної компетентності передбачає сформованість таких мовленнєвих навичок і вмінь:

- коректно вживати лексичні одиниці активного мінімуму (компетентності в говорінні й письмі) згідно із ситуаціями спілкування й цілями комунікації

- розпізнавати й розуміти лексичні одиниці активного й пасивного мінімумів при читанні й аудіюванні

- аналізувати англомовні джерела інформації для отримання даних, необхідних для виконання професійних завдань і прийняття професійних рішень

- користуватися різними видами словників (дво-, одномовних, фразеологічних, тематичних, країнознавчих) тощо.

Граматична компетентність (ГК) як здатність особистості до коректного граматичного оформлення своїх усних і писемних висловлювань і розуміння граматичного оформлення мовлення інших грунтується на складній і динамічній взаємодії відповідних навичок і знань і граматичної усвідомленості. Опанування студентами іншомовної граматичної компетентності передбачає передусім сформованість рецептивної й репродуктивної граматичних навичок і вмінь коректно вживати видо-часові форми й категорії стану дієслів; основні категорії іменника, прикметника, прислівника; артиклі; використовувати модальні дієслова і розуміти відтінки їхніх значень; правильно й доречно використовувати граматичні структури в різних мовленнєвих ситуаціях; складати різні речення (розповідні, питальні, спонукальні) залежно від мети спілкування й характеру мовленнєвого акту, а також демонструвати знання синтаксичної організації англійської мови в спілкуванні тощо.

Фонетична компетентність (ФК) як здатність людини до коректного артикуляційного й інтонаційного оформлення своїх висловлювань і розуміння мовлення інших грунтується на складній і динамічній взаємодії відповідних навичок, знань і фонетичної усвідомленості. Успішність формування ФК залежить від рівня сформованості фонетичних навичок, обсягу отриманих і засвоєних знань про фонетичну сторону мовлення і динамічної взаємодії цих складників на основі загальної мовної й фонетичної усвідомленості.

Компетентність у техниці письма (КТП) передбачає вдосконалення графічних, орфографічних і пунктуаційних навичок англійської мови 3 метою коректного графічного й орфографічного оформлення писемного висловлювання.

Компетентність у техниці читання (КТЧ) передбачає здатність людини до сприймання й коректного артикуляційного й інтонаційного декодування графічних знаків і письмових повідомлень, яка базується на складній і динамічній взаємодії відповідних навичок, знань 
та мовної усвідомленості. Успішність формування КТЧ залежить від рівня сформованості навичок ТЧ, обсягу отриманих і засвоєних знань у ТЧ і динамічної взаємодії цих складників на основі загальної мовної усвідомленості.

Основні вимоги до професійно орієнтованої мовленнєвої компетентності

1. В аудіюванні студенти (будуть) здатні:

Мовленнсві вміння:

- розуміти зміст автентичних текстів професійної спрямованості й текстів різних жанрів

- розуміти аудіо- й відеоматеріали з незначною кількістю незнайомої термінології

- розуміти основні ідеї та розпізнавати відповідну інформацію в ході обговорень, дебатів, доповідей, бесід, тематично пов'язаних з навчанням і спеціальністю

- розуміти обговорення проблем загальнонаукового й професійно орієнтованого характеру, що має на меті досягнення порозуміння

- розуміти повідомлення й інструкції в академічному й професійному середовищі

- розуміти намір мовця і комунікативні наслідки його висловлювання

- визначати позицію і точку зору мовця (визначати свою позицію і точку зору)

- виділяти в аудіотексті основну інформацію і прогнозувати його зміст

- вибирати головні факти, не звертаючи уваги на другорядні

• вибірково розуміти необхідну інформацію прагматичних текстів в опорі на мовну здогадку, контекст

- ігнорувати невідомий мовнй матеріал, несуттєвий для розуміння, тощо.

2. У говорінні студенти (будуть) здатні :

а) у діалогічному мовленні:

- брати участь у дискусіях з фахових питань; логічно й аргументовано висловлюватися з обговорюваних проблем, доводити свою точку зору і своє ставлення до них

- коректно реагувати на основні ідеї та розпізнавати суттєво важливу інформацію під час обговорень, дискусій, бесід, пов'язаних з навчанням і професією

- чітко аргументувати свою думку щодо актуальних тем в академічному й професійному житті (на конференціях, дискусіях в академічному навчальному середовищі)

- оперувати мовленнєвим етикетом спілкування: мовленнєвими зразками звертання, ввічливості, вибачення, погодження тощо

- адекватно поводитись у типових навчальних і професійних ситуаціях (на конференціях, дискусіях в академічному навчальному середовищі)

- готувати публічні виступи з галузевих питань, застосовуючи відповідні засоби вербальної комунікації й адекватні форми ведення дискусій і дебатів

- обговорювати навчальні й пов'язані зі спеціалізацією питання з метою досягнення порозуміння зі співрозмовником;

б) у монологічному мовленні:

- виступати з підготовленими індивідуальними презентаціями з широкого кола тем академічного й професійного спрямування

- робити повідомлення за вивченими темами

- продукувати чіткий доклад-монолог 3 широкого кола тем, пов'язаних 3 навчанням і спеціальністю

- без попередньої підготовки висловлювати свою думку у певних сферах фахового спілкуання, наводити свої аргументи й коректно реагувати (надавати коректні відповіді) на контраргументи

- достатньо повно передавати зміст прочитаного, побаченого або почутого, висловлюючи й обгрунтовуючи своє ставлення до осіб, подій, явищ, про які йдеться, тощо.

3. У читанні студенти (будуть) здатні:

- Ознайомлювальне читання: зрозуміти текст професійно спрямованої тематики, ідентифікувати основну інформацію, виокремити певні факти й аргументи. 
- Переглядове читання: визначити коло питань, які розглядаються в тексті, й основні думки автора тексту.

- Пошукове читання: знайти певну інформацію в довідкових джерелах; текстову, графічну, аудіо-/відео інформацію, вміщувану в англомовних галузевих матеріалах (як у друкованому, так і в електронному вигляді), користуючись відповідними пошуковими методами і термінологією.

- Вивчаюче читання: вільно, фонетично правильно читати текст загальноюридичного, соціально-політичного, країнознавчого й побутового характеру, укладений чи дібраний на основі вивченого лексико-граматичного матеріалу.

4. У письмі студенти (будуть) здатні:

- письмово викласти зміст прочитаного / прослуханого тексту, укладеного чи дібраного на основі вивченого лексико-граматичного матеріалу

- занотувати прослухане

- написати план і тези виступу

- написати $\mathrm{CV} /$ резюме

- написати твір / есе в межах вивченої тематики

- підготувати презентацію/доповідь для участі в конференціях тощо.

Лінгвосоціокультурна компетентність передбачає розвиток розуміння й тлумачення різних аспектів культури й мовленнсвої поведінки в професійному середовищі, формування вмінь, характерних для поведінки в різних культурних і професійних ситуаціях, і вмінь реагувати на них; умінь користуватись у процесі спілкування мовленнєвими реаліями (зразками), особливими правилами мовленнєвої поведінки, характерними для країни виучуваної мови.

Унаслідок опанування навчального курсу студент буде здатним:

- обговорювати навчальні й пов'язані зі спеціалізацією питання, щоб досягти порозуміння зі співрозмовником

- готувати публічні виступи з галузевих питань, застосовуючи відповідні засоби вербальної комунікації й адекватні форми ведення дискусій і дебатів

- знаходити нову текстову, графічну, аудіо-/відеоінформацію, яка міститься в англомовних галузевих матеріалах (як у друкованому, так і в електронному вигляді), користуючись відповідними пошуковими методами і термінологією

- аналізувати англомовні джерела інформації для отримання даних, необхідних для виконання професійних завдань і прийняття професійних рішень

- писати тексти і документи англійською мовою з низки професійних питань

- писати ділові й професійні листи, демонструючи міжкультурне розуміння й знання у конкретному професійному контексті

- писати анотації до неадаптованих текстів за фахом

- писати реферати на основі автентичної літератури за фахом

- складати тексти презентацій, використовуючи автентичні матеріали за фахом

- писати зрозумілі, деталізовані тексти різного спрямування, пов'язані з особистою й професійною сферами спілкування

- готувати та продукувати ділову та професійну кореспонденцію

- перекладати англомовні професійні тексти рідною мовою, користуючись двомовними термінологічними словниками, електронними словниками й програмним забезпеченням перекладацького спрямування

- розуміти автентичні тексти, пов'язані з навчанням та спеціальністю, з підручників, популярних і спеціалізованих журналів й інтернет-джерел

- розуміти головну ідею та знаходити необхідну інформацію в неадаптованій літературі за фахом

• передбачати основну інформацію тексту за його заголовком й ілюстративним матеріалом, який супроводжує текст 
- здійснювати ознайомлювальне читання неадаптованих текстів за фахом для отримання інформації

• накопичувати інформацію з різних джерел для подальшого її використання (на презентаціях, конференціях, дискусіях в академічному навчальному середовищі, а також у подальшій науководослідній роботі)

- здійснювати вивчаюче читання з метою поповнення термінологічного тезаурусу

- розуміти автентичну академічну й професійну кореспонденцію (листи, факси, електронні повідомлення, інструкції тощо)

• розуміти інформацію рекламних матеріалів тощо.

\section{Зміст навчальної дисципліни за темами}

\section{Module 1}

Unit 1.The Legal Profession.

Working in Law. A Career in Law. Areas of Law. The Sources of Law. People in the Law. Environment, Health, Science and Technology. Legal Training. Solicitors and Barristers. Making a Claim in the Civil Court.

Grammar. Tense Review:Present and Past Tenses.Types of Questions.

Unit 2. Civil Law.

Civil Legal System. Branches of Civil Law. The Law of Tort. Types of tort. The Duty of Care. The Tort of Negligence. Intellectual Property Law. Family Law. Accident and Injury: compensation and prevention.

Grammar. Tense Review: Future Tenses. Ways of Expressing the Future. Zero and First Conditionals.

\section{Module 2}

Unit 3. Business Law.

Sole traders. Partnerships. Companies. Incorporating a Company. Shares and Share Capital. The Language of Drafting. Paperwork.

Grammar: Second and Third Conditionals/Wishes/Unreal Past. Mixed Conditionals.

Unit 4. Employment law.

Working in Employment Law. Being an Employer. An Employment Contract. Acting for an Employer. Acting for an Employee. Employment Discrimination. An Employment Claim. Employee Health and Safety. Letter of Redundancy.

Grammar: Indirect Speech. The Sequence of Tenses.

\section{Module 3}

Unit 5. Company Law.

Areas of Company Law.Registration of New Companies. The Duties of the Directors. Company Meetings. Shareholders' Agreement. Company Finance. Share Capital. Insolvent Companies.

Grammar: Gerund and Infinitive. Complex Object/Subject.

Unit 6. Contract law.

Introduction to the Law of Contract. The Basics of Contract Law. Definitions and Types of Legal Contracts. The Elements of a Contract. Contract and Statute. Starting a Claim for Breach of Contract. Grammar: Defining and Non-defining Relative Clauses. Participles.

\section{Module 4}

Unit 7. Criminal Law.

Introduction to Criminal Law. Human Rights and Criminal Law. Morality and Criminal Law. Crime Categories. Types of Crime. Criminal Procedure. Sentencing.

At Trial. Key Players in the Criminal Law. On Appeal.

Grammar: Modal Auxiliary Verbs (Present, Future and Past) 
Unit 8. International Law.

International Organizations and Governance. Transnational Litigation, Arbitration, and Dispute Resolution. International Economic Law. International Criminal Law. Law of Armed Conflict and International Security. Public International Law. The UN. Developments in EU law. The International Court of Justice.

Grammar: Revision.

\section{Технології навчання}

Програма навчальної дисципліни “Англійська мова професійного спрямування" реалізується шляхом комплексного застосування сучасних освітніх технологій. Зокрема використовуються такі інноваційні освітні технології, як інтерактивна технологія навчання, модульно-рейтингова технологія, інформаційно-комунікативна технологія навчання (IКТ), проектна технологія, технологія співпраці, змішане навчання (Blended Learning), драматизація, скайп-технологія, навчання іноземних мов через зміст фахових дисциплін (CLIL), навчання через дію (learning by doing). Згадані технології навчання втілюються в організаційних формах учіння студентівюристів, зокрема дослідницьких міні-проектах (самостійних, індивідуальних, групових), роботі в малих групах, дискусіях у малих творчих групах, круглому столі, мозковому штурмі, кейсах, презентаціях, рольових іграх, дидактичних іграх, драматизації (постановці) судових засідань тощо.

\section{Індивідуальні завдання й консультативна робота}

Основна мета індивідуальних завдань 3 іноземної мови професійного спрямування поглиблення практичних навичок і вмінь володіння англійською мовою, стимулювання залучення різних джерел і засобів інформації й заохочення студентів до творчої роботи.

3 метою розвитку основ перекладу професійно орієнтованих іншомовних джерел і вмінь опрацювання фахових текстів рекомендуються такі індивідуальні завдання:

- письмовий переклад текстів за фахом з друкованих джерел (фахова й загальна періодика)

- письмовий переклад текстів за фахом з інтернету

- складання термінологічних словників за фаховими текстами

- виконання творчих завдань, спрямованих на поглиблення й удосконалення вмінь говоріння, читання, письма

- написання і захист рефератів і наукових статей

- складання CV

- написання навчальних сценаріїв судових засідань й участь в їх постановці

- підготовка і захист презентацій.

На індивідуальних заняттях уточнюються й з'ясовуються всі питання, які виникають у студентів під час самостійного опрацювання текстів, і подається звіт. Звіт може мати форму бібліографічної добірки статей загальнонаукового й фахового змісту, вибіркового усного й письмового перекладу, усних й письмових анотацій і рефератів прочитаного, узагальнення матеріалу за окремими статтями (оглядове реферування), стислих повідомлень і доповідей іноземною мовою за змістом опрацьованого матеріалу.

\section{Рекомендована література}

Основна

1. Antonia Clare, JJ Wilson. "Speak Out" My English Lab, Upper Intermediate, Pearson, 2015

2. Catherine Mason, Rosemary Atkins. "The Lawyer's English Language Coursebook". Cambridge, 2007.

3. Мельник Г.М. Збірник тестових завдань для поточного контролю рівня сформованості граматичних умінь студентів 1 та 2 курсів. Збірник тестових завдань. К.:КНЕУ. 2010.

4. Rawdon Wyatt. "Check your English Vocabulary for Law". A\&C Black. London, 2006.

5. Nick Brieger. "Professional English. Law.” Pearson, 2003. 
6. Боровецька Л.В., Жукова Л.Т., Сініцина Н.М. та ін. Ділова англійська мова для юристів. Навчальний посібник. Київ, КНЕУ. 2006

7. Dictionary of Law, 5th edition / edited by Ned Beale, 2007.

8. Virginia Evans. "FCE Use of English". Express Publishing, 2001.

9. Песочин А.А., Юрчук П.С. “Практический курс английского язика для юристов”. - Харьков: Консум, 2002.

\section{Додаткова}

1. Методика навчання іноземних мов і культур: теорія і практика. Київ, “Ленвіт”, 2013.

2. English for Specific Purposes (ESP) National Curricilim for Universities. Київ, “Ленвіт”, 2005.

3. Amy Krois-Linder. "International Legal English". Cambridge University Press, 2008.

4. Чуркіна О.В. Навчально-методичний посібник для самостійного вивчення дисципліни

"English for students of economics and law", P.II, K.: KHEУ. 2006;

5. F.Russel, Ch.Locke. English Law and Language. An introduction for students of English.

6. R.Murphy. English Grammar in Use.

7. Сімонок В. П. Посібник з англійської мови для студентів-юристів - Харків : Право, 2005.

8. Evants, V., Dooly, J., Smith, D.J. Law: Career Paths / V. Evants, J. Dooly, D. J. Smith. - Express Publishing, 2011.

9. J. Shaw. "Economic and Social Law of the European Union"/ J. Shaw. - Palgrave Macmillan, 2007.

10. A. Riley. "EnglishforLaw"/ A. Riley - Longman, 2001.

11. Amy Krois-Linder. "Introduction to International Legal English”. Cambridge University Press, 2008.

12. Gillian D. Brown, Sally Rice. "Professional English in Use Law". Cambridge University Press, 2009.

\section{Інтернет ресурси}

1. www.icc-cpi.int - Міжнародний Кримінальний суд.

2. http://www.icj-cij.org/ - Міжнародний суд.

3. http://.interpol.int - Інтерпол.

4. http://www.europol.europa.eu/ - Свропол.

5. www.worldcourts.com/index-ru.htm - Міжнародні суди.

6. www.justice.gov - US Department of Justice

7. http://www.scotusblog.com/ - Supreme Court of the United States.

8. http://criticallegalthinking.com/ - CLT is a platform for critical legal scholars and allies to publish theoretically informed comment and analysis.

9. https://www.law.com/legaltechnews - A rich selection of articles curated by ALM's expert editorial team from across ALM's national and regional publications, featuring leading voices in the legal field. 10. https://www.lexblog.com/ - Lex Blog started with a simple idea. Lawyers need to write online. 11. http://stories.avvo.com/ - Avvo helps attorneys grow their practice by easily connecting them with the millions of people searching for legal help every month. 